\title{
Business Development Strategies Using SWOT Analysis in the Cahaya Modern Home Industry
}

\author{
Deby Riska Sonia ${ }^{1}$, Arwin Sanjaya ${ }^{2}$, Marnala Joshua Hutajulu ${ }^{3}$ \\ $1,2,3$ Universitas Mulawarman Samarinda \\ Email: debysonia@gmail.com ${ }^{1}$, arwinsy@ fisip.unmul.ac.id ${ }^{2}$, \\ marnalahutajulu@ fisip.unmul.com ${ }^{3}$
}

\begin{abstract}
The purpose of this study is to determine the internal conditions (Strengths, Weaknesses) and external (Opportunities, Threats) of Cahaya Modern SMEs using SWOT, so it can be identified which strategies can be used for business development. The type of research used is kualitatif. The conclusion of this research is there are strength and weakness factors that influence the internal conditions of Cahaya Modern SMEs. Those are the workers that live nearby the business location and sales promotion that are still offline. The opportunities and threat factors that influence external conditions are fostered by the government and the existence of substitute products. Based on the calculation of IE Cahaya Modern SMEs matrix lies in quadrant II which means Grow and Build. There are alternative business development strategies obtained from data processing using QSPM. First is making alternative products using additional raw materials, incorporating technological sophistication in producing products, maintaining quality and showing excellence, adjusting consumer demand, optimizing marketing, being active in government activities, and utilizing technological advancements as an act of promotion. The main priority result of the analysis is to make alternative products using additional raw materials with a TAS of 5.62 .
\end{abstract}

Keywords: Business Development, IE Matrix, SWOT Analysis, QSPM.

\section{INTRODUCTION}

The high level of economic growth in Indonesia is estimated to be able to reach above $6 \%$, making the potential for developing Small and Medium Enterprises (SMEs) still relatively high in Indonesia. SMEs continue to be encouraged by the government to grow and develop through the Ministry of Cooperatives and Small and Medium Enterprises collaborating with the marketplace (Rakib \& Arifin, 2018; Rengifurwarin et al., 2018). Efforts by the government include helping to promote through exhibitions, as well as. However, the development of SMEs still faces many obstacles in various sectors so that the market opportunities obtained have not been so high (Agyemang \& Ansong, 2017; Stankovska, 2016; Yaseen, 2019). Some ways can be done by businesses to develop their businesses one of them is through a SWOT analysis. SWOT analysis can be used to analyze how business strategies must be run. SWOT analysis is the systematic identification of various factors to formulate a company's strategy. According to Rangkuti (2019) this analysis is based on logic that can maximize strengths and opportunities, but simultaneously can minimize weaknesses and threats. Meanwhile, according to Nur'Aini \& Fatimah (2016) SWOT analysis is a classical strategy planning instrument that provides a simple way to estimate the best way to determine a strategy. As according to Sabariah (2016) 
118 Jurnal Administrare: Jurnal Pemikiran Ilmiah dan Pendidikan Administrasi Perkantoran

Vol. 7, No. 1, January - June 2020, Pages 117-128

SWOT analysis is an analysis of information obtained, sought, or received from various sources of results from the question of what is happening, why it happened, where it happened and when it happened, all of which came from internal and external companies related to the business company. The application of SWOT analysis in a company aims to provide a guide so that the company becomes more focused, so that the placement of the SWOT analysis can later be used as a comparative thought from various perspectives, both in terms of strengths and weaknesses as well as opportunities for threats that might occur in the future. the future (Fahmi, 2013). Every business must have a problem in its business activities, and the problem faced by Cahaya Modern SMEs from an internal perspective is that there is no partnership development being undertaken. Retrieval of raw materials in the Benamang area which requires a distance of approximately 4 hours is also carried out directly by the business owner using a motorcycle. Because using a motorcycle also the carrying capacity in transporting raw materials is only a little, as well as at the time of the exhibition, making business owners experience limitations in transporting finished goods to be exhibited. Other internal problems, namely promotions carried out only offline. While external problems, namely the scarcity of raw materials, which are now difficult to find, are the main problems in the production process. In addition, the rainy season is also an obstacle to taking raw materials for making mortar, the rainy season causes muddy roads so that the process of collecting raw materials is hampered. Some of the problems above are factors that are included in the cause of decline in sales of Cahaya Modern SMEs, these can be seen in table 1:

Table 1. Cobek Sales Data for 2016-2018

\begin{tabular}{cc}
\hline Years & The Sale (Pcs) \\
\hline 2016 & 690 \\
2017 & 600 \\
2018 & 500 \\
\hline
\end{tabular}

Source: Cahaya Modern SMEs

In developing a business that was once small to become big is not something easy. An entrepreneur must strive so that this can be achieved. For the sake of the development of a business, an entrepreneur can leave personal matters for the achievement of the development of their business. An entrepreneur must struggle with using special tactics so that their business can be successful and large. To be successful, an entrepreneur must work hard, be smart and never give up. This must be done so that an entrepreneur understands the purpose of the purpose and function of how to develop a small business into a large one. According to (Rengifurwarin et al. (2018) business development is essentially a shared responsibility between the government and the community. By looking at the problems faced by a business, efforts are needed such things as: a) Creation of a conducive business climate, b) Capital assistance, c) Business protection, d) Partnership Development, e) Training, f) Develop promotions, and g) Develop equal cooperation.

As according to Budiarta (2009) in developing a business, an entrepreneur generally conducts business development through several stages of business activity development, as follows: a) Have a business idea, b) Screening business ideas or concepts, c) Development of a business plan (business plan), d) Implementation of business plans and business control. 
Before conducting a SWOT analysis, the first thing to do to find a good business development strategy is environmental scanning. Environmental scanning is scanning the variables contained in the internal environment and external environment. The most important variables in the internal environment are the strengths and weaknesses of the organization, while the most important variables in the external environment are opportunities and threats (Indrajit, 2013). After knowing what are the internal and external factors of the Cahaya Modern SMEs the next stage is to do calculations on IFAS and EFAS matrices, Internal-External matrix (IE) to position the company into a matrix consisting of 9 cells (H Setyorini et al., 2016), SWOT matrix, and Quantitative Strategic Planning Matrix (QSPM) which objectively shows which strategy is best (Barak \& Javanmard, 2020; Ghorbani et al., 2015; Mallick et al., 2020). The purpose of this study is to determine the internal conditions (Strenghts, Weaknesses) and external (Opportunities, Threats) of Cahaya Modern SMEs by using SWOT analysis so it is known which strategies can be used for business development in Cahaya Modern SMEs.

\section{METHOD}

This research was a qualitative research. The focus or limitation in this research was internal factors (strengths, weaknesses) and external factors (opportunities, threats) that existed in Cahaya Modern SMEs. There were two types of data sources, namely primary data (key informants and supporting informants) and secondary data (websites or reference books). The data collection in this study used interview techniques between researchers and speakers, observations or observations to determine the target under study. The analysis technique used in this study was a SWOT analysis with IFAS and EFAS calculations, Internal-External matrix (IE), SWOT matrix, and Quantitative Strategic Planning Matrix (QSPM).

Before calculating the IFAS and EFAS matrices, the weight, rating and score values for each indicator of strengths, weaknesses, opportunities and threats were sought first. Weights were determined by comparing each horizontal indicator with a vertical indicator. Strengths and weaknesses ware compared with strengths and weaknesses too, and so on up to opportunities and threats. In the rating calculation there were 4 scales, namely the value of 4 was very influential, 3 was influential, 2 was quite influential, and 1 was not influential. The score value was obtained based on the results of the weight value times the rating value (Rangkuti, 2016).

Weight:

$1=$ horizontal indicators are less important than vertical indicators

$2=$ horizontal indicator is just as important as the vertical indicator

$3=$ horizontal indicators are more important than vertical indicators

Rating:

$4=$ very influential

$3=$ influential

$2=$ quite influential

$1=$ not influential

Score $=$ Weight $\mathrm{x}$ Rating 
120 Jurnal Administrare: Jurnal Pemikiran Ilmiah dan Pendidikan Administrasi Perkantoran

Vol. 7, No. 1, January - June 2020, Pages 117-128

\section{RESULT AND DISCUSSION}

\section{Internal environmental analysis}

The following is a scan of the Cahaya Modern SMEs internal environment according to Wheelen \& Hunger (2011):

1. Structure: chain of command

Cahaya Modern only has 3 parts of duties and authority that govern the running of the business, namely the business owner, assistant, and the production department. In a study conducted by Landombela, Memah, and Loho (2018) the object under study had 2 organizational structures, namely the business owner and the production department as a bamboo cutter and sanding.

2. Culture: beliefs, expectations, values

Culture is the same as what is the vision and mission of Cahaya Modern SMEs, what is the vision and mission is also the basis of the culture of Cahaya Modern SMEs to achieve its goals and targets.

3. Resources: assets, skills competencies, knowledge

Business owners have the ability and skills in processing handicrafts with basic materials in the form of wood. This is proven by the number of products that have been made by business owners that are very diverse and detailed. By being fostered by the government the business owner also gets knowledge on how to manage and develop his business. Likewise, research conducted by Landombela, Memah, and Loho (2018), business owners and craftsmen rely heavily on their skills and accuracy in order to obtain durable product results.

From the process of environmental scanning and interviews obtained several strengths and weaknesses. Strengths and weaknesses can be seen in table 2 .

\section{Analysis of the external environment}

The following is a scan of the external environment of Cahaya Modern SMEs according to Wheelen \& Hunger (2011):

1. Societal environment: general forces

In the environmental aspect, Cahaya Modern SMEs is located in Sebulu Modern Village. The distance from the city center is quite far, about 40 minutes, but the access road to Cahaya Modern SMEs is easy to reach even though you have to cross the river first by ferry. UD Betris which is the object of research by Landombela, Memah, and Loho (2018) is a home-based business or home industry in which the location of the business is utilizing a private house or house where the business owner lives as the Cahaya Modern SMEs. Both of these efforts are equally utilizing government support by participating in various exhibition activities carried out by the government.

2. Task Environment: Industry analysis

The industry of making handicrafts based on ironwood is still very difficult to find. A mortar that is always needed and has become a basic tool for making chili sauce that will be used continuously makes the opportunity for Cahaya Modern SMEs to continue to develop. But 
technological advances are also a threat to companies that still use traditional equipment. The development of technology became a factor that influenced UD Betris's external environment in the research of Landombela, Memah, and Loho (2018) and Cahaya Modern SMEs, for example the emergence of new competitors using modern equipment.

From the process of environmental scanning and interviews obtained several opportunities and threats. Opportunities and threats can be seen in table 3.

\section{Internal Factors Analysis Summary (IFAS)}

IFAS illustrated the magnitude of influence between internal factors on the strategy making of a company or business (Rangkuti, 2016).

\section{Table 2.}

Internal Factors Analysis Summary (IFAS)

\begin{tabular}{|c|c|c|c|c|}
\hline No & Internal Ratio Factors & $\begin{array}{c}\text { Average } \\
\text { Weight }\end{array}$ & $\begin{array}{c}\text { Average } \\
\text { Rating }\end{array}$ & Score \\
\hline \multicolumn{5}{|c|}{ Strengths } \\
\hline 1 & Have capital assistance & 0,0485 & 3 & 0,1455 \\
\hline 2 & $\begin{array}{l}\text { Have a Micro Small Business Permit (IUMK) } \\
\text { The owner has done training }\end{array}$ & 0,05 & 3,5 & 0,175 \\
\hline 3 & Party prices available & 0,05 & 3 & 0,15 \\
\hline 4 & Many variations of product models & 0,068 & 2,5 & 0,17 \\
\hline 5 & Can be ordered in large quantities & 0,0575 & 3 & 0,1725 \\
\hline 6 & Pay close attention to product details & 0,056 & 3 & 0,168 \\
\hline 7 & Business owners communicate very well with & 0,0545 & 3 & 0,1635 \\
\hline 8 & consumers & 0,059 & 3 & 0,177 \\
\hline 9 & Workers close to the business location & 0,061 & 3 & 0,183 \\
\hline \multicolumn{5}{|c|}{ Weaknesses } \\
\hline 1 & The business climate is not conducive yet & 0,052 & 3,5 & 0,182 \\
\hline 2 & Do not have permanent business partners & 0,0515 & 2,5 & 0,1288 \\
\hline 3 & $\begin{array}{l}\text { Various types of activities must be handled by } \\
\text { business owners }\end{array}$ & 0,0515 & 3,5 & 0,1802 \\
\hline 4 & Production equipment is still very traditional & 0,061 & 3 & 0,183 \\
\hline 5 & $\begin{array}{l}\text { HR's knowledge of internet technology as a } \\
\text { promotional medium is still limited } \\
\text { Sales promotions are still offline }\end{array}$ & 0,054 & 3,5 & 0,189 \\
\hline 6 & Inadequate transport vehicle & 0,0585 & 3,5 & 0,2048 \\
\hline 7 & Lack of public knowledge about the health & 0,0515 & 3,5 & 0,1802 \\
\hline 8 & function of wooden mortars & 0,0605 & 3 & 0,1815 \\
\hline 9 & $\begin{array}{l}\text { The financial statements have not been arranged } \\
\text { properly }\end{array}$ & 0,055 & 3,5 & 0,1925 \\
\hline & IFAS Total Score & 1 & & 3,12 \\
\hline
\end{tabular}


122 Jurnal Administrare: Jurnal Pemikiran Ilmiah dan Pendidikan Administrasi Perkantoran Vol. 7, No. 1, January - June 2020, Pages 117-128

\section{External Factors Analysis Summary (EFAS)}

EFAS illustrated the magnitude of influence between external factors on the strategy making of a company or business (Rangkuti, 2016).

Table 3

External Factors Analysis Summary (EFAS)

\begin{tabular}{|c|c|c|c|c|}
\hline No & External Ratio Factors & $\begin{array}{c}\text { Average } \\
\text { Weight }\end{array}$ & $\begin{array}{c}\text { Average } \\
\text { Rating }\end{array}$ & Score \\
\hline \multicolumn{5}{|c|}{ Opportunities } \\
\hline 1 & $\begin{array}{l}\text { Cahaya Modern MSME is fostered by the } \\
\text { government }\end{array}$ & 0,0915 & 4 & 0,366 \\
\hline 2 & $\begin{array}{l}\text { There are many events in East Kalimantan that } \\
\text { can be used as a promotional tool }\end{array}$ & 0,093 & 3 & 0,279 \\
\hline 3 & $\begin{array}{l}\text { The lifestyle of consumers is still using a } \\
\text { mortar } \\
\text { Market share is still wide }\end{array}$ & 0,091 & 3 & 0,273 \\
\hline 4 & The export market is still open & 0,0915 & 2,5 & 0,2288 \\
\hline 5 & & 0,0915 & 2,5 & 0,2288 \\
\hline \multicolumn{5}{|c|}{ Threats } \\
\hline 1 & The raw material for making mortar is hard to & 0,0895 & 3,5 & 0,3132 \\
\hline 2 & get & 0,093 & 3,5 & 0,3255 \\
\hline 3 & The emergence of a similar business & 0,093 & 4 & 0,372 \\
\hline 4 & Substitution products or mortar substitutes & 0,0775 & 3,5 & 0,2712 \\
\hline 5 & $\begin{array}{l}\text { raw materials } \\
\text { There is price competition }\end{array}$ & 0,095 & 3 & 0,285 \\
\hline 6 & Regeneration of productive labor is reduced & 0,0935 & 3 & 0,2805 \\
\hline & EFAS Total Score & 1 & & 2,90 \\
\hline
\end{tabular}

In the IE matrix above, the value indicates the quadrant II position, which showed the strategy needed for Cahaya Modern SMEs today is Grow and Build. Grow and Build showed that Cahaya Modern SMEs need a strategy to grow and develop more. The strategies that could be applied by UMKM Cahaya Modern were market penetration, market development, product development or integration (backward integration, forward integration, and horizontal integration) (Hany Setyorini \& Santoso, 2017). These results were similar to the study conducted by Hany Setyorini \& Santoso (2017) at WS Soekarno Hatta Malang Restaurant, the results of the IE matrix were in quadrant IV position with coordinates X 2.798 and Y 3.181. The strategy that matched the IV quadrant was Grow and Build.

\section{Matriks Internal-Eksternal (IE)}

Based on the results of the IFAS and EFAS matrices, according to David Fred R the next step is to compile the results of the IFAS and EFAS matrices into the IE matrix. The IFAS 
(3.12) and EFAS (2.90) matrices are entered into the IE matrix. The resulting coordinate point functions to see the position of the Cahaya Modern SMEs through the IE matrix. Following IE Cahaya Modern MSME Matrix:

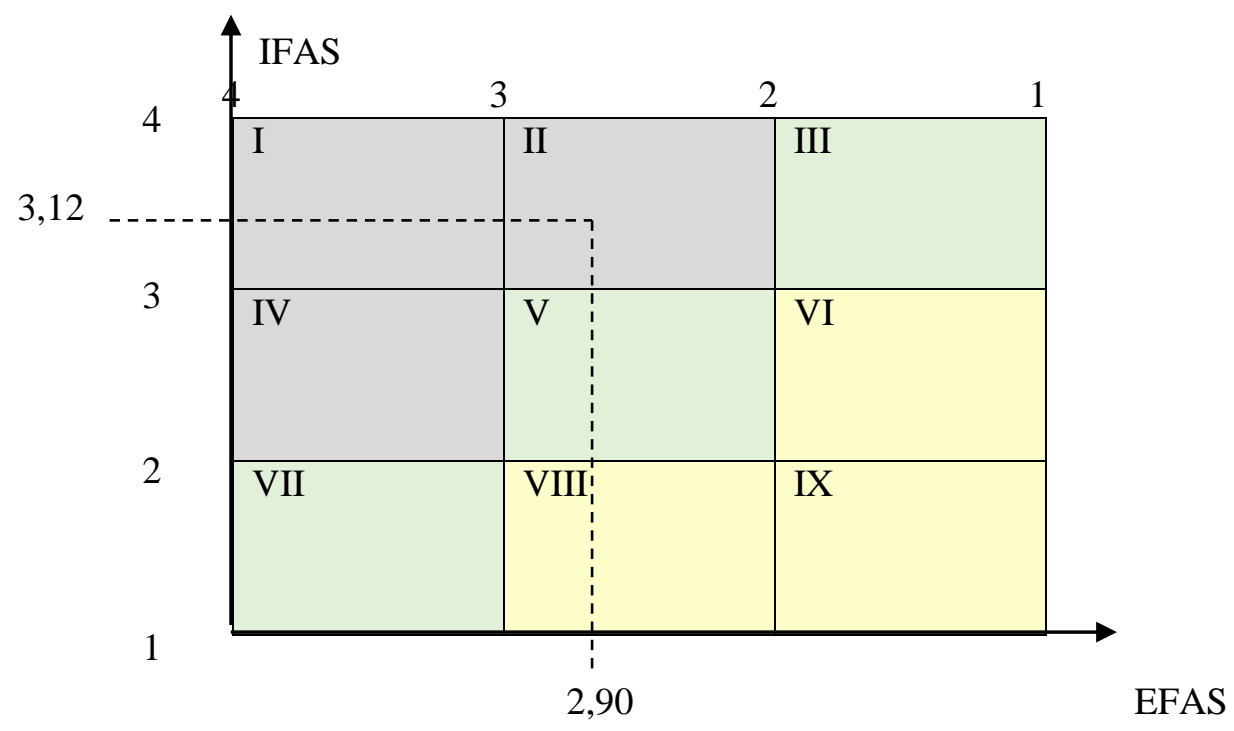

Picture 1.

Cahaya Modern SMEs IE Matrix

In the IE matrix above, the value indicates the quadrant II position, which showed the strategy needed for Cahaya Modern SMEs today is Grow and Build. Grow and Build showed that Cahaya Modern SMEs need a strategy to grow and develop more. The strategies that could be applied by Cahaya Modern SMEs were market penetration, market development, product development or integration (backward integration, forward integration, and horizontal integration) (Hany Setyorini \& Santoso, 2017). These results were similar to the study conducted by Hany Setyorini \& Santoso (2017) at WS Soekarno Hatta Malang Restaurant, the results of the IE matrix were in quadrant IV position with coordinates X 2.798 and Y 3.181. The strategy that matched the IV quadrant was Grow and Build.

\section{SWOT Matrix}

According to Rangkuti (2016) the SWOT matrix was a tool used to compile corporate strategic factors. The SWOT matrix produced 4 sets of possible alternative strategies that could be used, namely SO (Strengths and Opportunities), ST (Strengths and Threats) strategies, WO strategies (Weaknesses and Opportunities), and WT (Weaknesses and Threats) strategies. These following were alternative strategies that have been formulated into the SWOT matrix: 

124 Jurnal Administrare: Jurnal Pemikiran Ilmiah dan Pendidikan Administrasi Perkantoran
Vol. 7, No. 1, January - June 2020, Pages $117-128$

Table 4

SWOT Matrix

\begin{tabular}{|c|c|c|}
\hline EFAS & $\begin{array}{l}\text { STRENGTHS (S) } \\
\text { 1. Have capital assistance } \\
\text { 2. Have a Micro Small } \\
\text { Business Permit (IUMK) } \\
\text { 3. The owner has done } \\
\text { training } \\
\text { 4. Party prices available } \\
\text { 5. Many variations of } \\
\text { product models } \\
\text { 6. Can be ordered in large } \\
\text { quantities } \\
\text { 7. Pay close attention to } \\
\text { product details so that the } \\
\text { products are of high } \\
\text { quality such as raw } \\
\text { materials that have } \\
\text { medicinal properties } \\
\text { 8. Business owners } \\
\text { communicate very well } \\
\text { with consumers } \\
\text { 9. Workers close to the } \\
\text { business location }\end{array}$ & $\begin{array}{l}\text { WEAKNESSES (W) } \\
\text { 1. The business climate is } \\
\text { not conducive yet } \\
\text { 2. Do not have permanent } \\
\text { business partners } \\
\text { 3. Various types of } \\
\text { activities must be } \\
\text { handled by business } \\
\text { owners, including } \\
\text { production activities } \\
\text { that must still be fully } \\
\text { handled by the business } \\
\text { owner } \\
\text { 1. Production equipment is } \\
\text { still very traditional } \\
\text { 2. HR knowledge of } \\
\text { internet technology as a } \\
\text { promotional medium is } \\
\text { limited } \\
\text { 3. Sales promotions are } \\
\text { still offline } \\
\text { 4. Inadequate transport } \\
\text { vehicle } \\
\text { 5. Lack of public } \\
\text { knowledge about the } \\
\text { health function of } \\
\text { wooden mortars } \\
\text { 6he financial report } \\
\text { have not been arranged } \\
\text { properly }\end{array}$ \\
\hline $\begin{array}{l}\text { OPPORTUNITIES (O) } \\
\text { 1. Fostered by the } \\
\text { government (Department } \\
\text { of Industry, Trade and } \\
\text { Cooperatives) } \\
\text { 2. Many traditional events as } \\
\text { a means of promotion } \\
\text { 3. Consumer lifestyle } \\
\text { 4. Large market share } \\
\text { 5. Opening of the export } \\
\text { market }\end{array}$ & \begin{tabular}{ll}
\multicolumn{1}{c}{ SO STRATEGY } \\
1. Using government \\
assistance to produce a \\
greater number of \\
products $\left(\mathrm{S}_{2}, \mathrm{~S}_{6}, \mathrm{~S}_{9}, \mathrm{O}_{1}\right.$, \\
$\left.\mathrm{O}_{4}, \mathrm{O}_{5}\right)$ \\
2. $\begin{array}{l}\text { Optimize product } \\
\text { marketing }\left(\mathrm{S}_{1}, \mathrm{~S}_{2}, \mathrm{~S}_{3}, \mathrm{O}_{1},\right. \\
\left.\mathrm{O}_{4}, \mathrm{O}_{5}\right) \\
\text { 3. }\end{array}$ \\
Active in activities \\
carried out by the \\
government $\left(\mathrm{S}_{1}, \mathrm{~S}_{2}, \mathrm{~S}_{8}\right.$,
\end{tabular} & 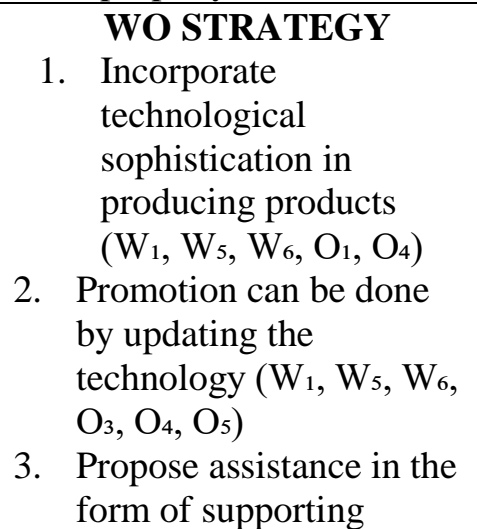 \\
\hline
\end{tabular}




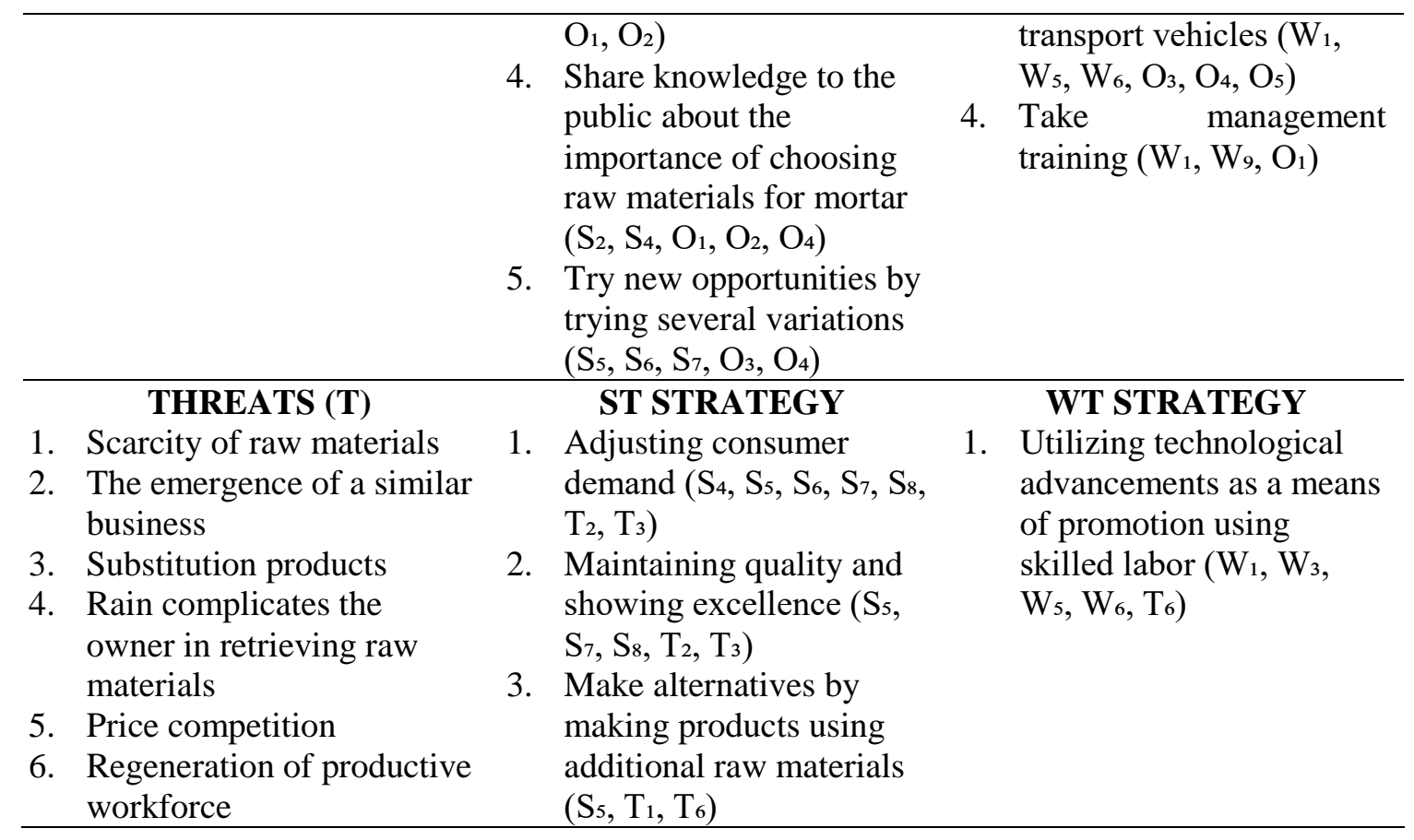

\section{Quantitative Strategic Planning Matrix (QSPM)}

After obtaining a number of alternative strategies through the SWOT matrix, the next stage was the selection of an appropriate and good strategy for Cahaya Modern SMEs. The analytical tool used was the Quantitative Strategic Planning Matrix (QSPM) or quantitative strategy planning matrix. The method of calculation was to multiply the weights on each indicator by the attractiveness score (AS).

The following was a sequence of alternative strategies that can be used by Cahaya Modern SMEs sorted by the results of the largest to the smallest TAS. The greater the TAS score, the more alternative strategies were needed:

1. Make alternatives by making products using additional raw materials (TAS $=5.26$ )

2. Incorporate technological sophistication in producing products $(\mathrm{TAS}=5$ )

3. Maintaining quality and showing excellence (TAS $=4.79)$

4. Adjusting consumer demand (TAS $=4.53$ )

5. Optimizing product marketing (TAS $=4.41$ )

6. Active in activities carried out by the government (TAS $=3.74$ )

7. Utilizing technological advancements as a means of promotion by using a skilled workforce (TAS $=3.45$ )

Slightly different from the results of previous studies conducted by Hany Setyorini \& Santoso (2017), but the results of the QSPM matrix calculation both lead to the need for innovation and product development. Product development can be done to develop existing products by changing forms or creating new products into existing markets. 


\author{
126 Jurnal Administrare: Jurnal Pemikiran Ilmiah dan Pendidikan Administrasi Perkantoran \\ Vol. 7, No. 1, January - June 2020, Pages 117-128
}

\title{
CONCLUSION
}

The results of the analysis of the internal environmental conditions show the highest strength factor for Cahaya Modern SMEs, which is the labor close to the business location. While the analysis of internal environmental conditions on the dominant weakness factor is the promotion of sales of Cahaya Modern SMEs that are still offline. The results of the analysis of the external environmental conditions indicate the highest opportunity factor for Cahaya Modern SMEs, namely Cahaya Modern SMEs fostered by the Department of Industry, Trade, and Cooperatives (Disperindagkop). While the analysis of external environmental conditions on the threat factor that gets the highest results is the existence of a substitute product. Based on the results of calculations on the Internal-External matrix, the position of Cahaya Modern SMEs is located in quadrant II, namely Grow and Build, business development strategies that can be applied by Cahaya Modern SMEs are market penetration, market development, product development or integration (backward integration, integration into front, and horizontal integration). Other alternative business development strategies obtained from data processing using the Quantitative Strategic Planning Matrix (QSPM) are making alternatives by making products using additional raw materials, incorporating technological sophistication in producing products, maintaining quality and showing excellence, adjusting consumer demand and optimizing product marketing, active in activities carried out by the government, utilizing technological advances as a means of promotion by using a skilled workforce. The main priority result of the analysis is to make alternatives by making products using additional raw materials with a TAS of 5.62 .

\section{REFERENCES}

Agyemang, O. S., \& Ansong, A. (2017). Corporate social responsibility and firm performance of Ghanaian SMEs. Journal of Global Responsibility, 8(1), 47-62. https://doi.org/10.1108/jgr-03-2016-0007

Barak, S., \& Javanmard, S. (2020). Outsourcing modelling using a novel interval-valued fuzzy quantitative strategic planning matrix (QSPM) and multiple criteria decisionmaking (MCDMs). International Journal of Production Economics, 222, 107494. https://doi.org/https://doi.org/10.1016/j.ijpe.2019.09.015

Budiarta, K. (2009). Pengantar Bisnis. Jakarta: Mitra Wacana Media.

Fahmi, I. (2013). Manajemen Strategis Teori dan Aplikasi. Bandung: Alfabeta.

Ghorbani, A., Raufirad, V., Rafiaani, P., \& Azadi, H. (2015). Ecotourism sustainable development strategies using SWOT and QSPM model: A case study of Kaji Namakzar Wetland, South Khorasan Province, Iran. Tourism Management Perspectives, 16, 290-297. https://doi.org/https://doi.org/10.1016/j.tmp.2015.09.005

Mallick, S. K., Rudra, S., \& Samanta, R. (2020). Sustainable ecotourism development 
using SWOT and QSPM approach: A study on Rameswaram, Tamil Nadu. International Journal of Geoheritage and Parks. https://doi.org/https://doi.org/10.1016/j.ijgeop.2020.06.001

Memah, M. Y., \& Loho, A. E. (2018). Strategi Pengembangan Usaha Industri Kerajinan Bambu Batik UD. Betris di Kelurahan Meras Kecamatan Bunaken Kota Manado. AGRI-SOSIOEKONOMI, 14(3), 79-88.

Nur'Aini, F., \& Fatimah, D. (2016). Teknik Analisis SWOT. Quadrant, Yogyakarta.

Rakib, M., \& Arifin, M. (2018). Standardization of Small Businesses: A Feasibility Study of Restaurants in Enrekang Regency. Jurnal Ilmiah Ilmu Administrasi Publik, 8(1), 69-78.

Rangkuti, F. (2019). Teknik Membedah Kasus Bisnis.

Rengifurwarin, Z. A., Akib, H., \& Salam, R. (2018). Snapshot of public service quality in the center for integrated business service (CIBS), cooperative micro small and medium enterprises (CMSME), Maluku Province, Indonesia. Journal of Entrepreneurship Education.

Sabariah, E. (2016). Manajemen Strategi. Yogyakarta: Pustaka Pelajar.

Setyorini, H., Effendi, M., \& Santoso, I. (2016). Analisis Strategi Pemasaran Menggunakan Metode Quantitative Strategi Planning Matrix (Qspm). Jurnal Teknologi Dan Manajemen Agroindustri, 5(1), 46-53.

Setyorini, H., \& Santoso, I. (2017). Analisis Strategi Pemasaran Menggunakan Matriks SWOT dan QSPM (Studi Kasus: Restoran WS Soekarno Hatta Malang). Industria: Jurnal Teknologi Dan Manajemen Agroindustri, 5(1), 46-53.

Stankovska, I. (2016). Digital channels diminish SME barriers: The case of the UK. Economic Research-Ekonomska Istrazivanja, 29(1), 217-232. https://doi.org/10.1080/1331677X.2016.1164926

Wheelen, T. L., \& Hunger, J. D. (2011). Concepts in strategic management and business policy. Pearson Education India.

Yaseen, H. (2019). Digital marketing adoption among smes in Jordan: A mixed-method approach. Journal of Theoretical and Applied Information Technology, 97(4), 1396-1407. 